Volume 12, Nomor 2, April 2021, p.083-101

Faculty of Law, Universitas Kristen Maranatha

ISSN: 2085-9945 I e-ISSN: 2579-3520

Nationally Accredited Journal by SINTA

\title{
OPTIMALISASI HAK PEMEGANG SAHAM ATAS KEWENANGAN OJK DALAM PELAKSANAAN AKUISISI LEMBAGA JASA KEUANGAN BANK PADA MASA PANDEMI COVID-19
}

\author{
Andrea Sukmadilaga, R. Kartikasari, Ema Rahmawati \\ Faculty of Law, Padjajaran University \\ asukmadilaga@gmail.com
}

\begin{tabular}{|c|c|}
\hline \multicolumn{2}{|c|}{ Submitted: 2021-03-05 | Reviewed: 2021-03-17| Accepted: 2021-04-13 } \\
\hline $\begin{array}{l}\text { How to cite: } \text { Andrea Sukmadilaga, R. } \\
\text { Kartikasari, Ema Rahmawati. } \\
\text { "Optimalisasi Hak Pemegang Saham } \\
\text { atas Kewenangan OJK dalam } \\
\text { Pelaksanaan Akuisisi Lembaga Jasa } \\
\text { Keuangan Bank pada Masa Pandemi } \\
\text { Covid - 19". Dialogia Iuridica: Jurnal } \\
\text { Hukum Bisnis dan Investasi, Vol. 12, } \\
\text { No. 2, (2021): 083-101. }\end{array}$ & $\begin{array}{l}\text { ABSTRACT } \\
\text { After the issuance of PERPPU Number } 1 \text { of } 2020 \\
\text { concerning State Financial Policy and Financial } \\
\text { System Stability for Handling the Corona Virus } \\
\text { Disease } 2019 \text { (COVID-19) Pandemic and / or in the } \\
\text { Context of Facing Threats That Endanger the National } \\
\text { Economy and / or Financial System Stability, OJK can } \\
\text { give written orders for the Bank to conduct } \\
\text { restructuring, one of which is the Acquisition and is } \\
\text { authorized to conduct due diligence on prospective } \\
\text { Bank Controlling Shareholders. The method used in } \\
\text { writing this article is a normative juridical research } \\
\text { with a statutory and conceptual approach. The results } \\
\text { of the discussion show that the authority of the OJK in } \\
\text { implementing the Acquisition has not taken into } \\
\text { account the Shareholders' Rights guaranteed in the } \\
\text { Company Law as well as any illegal actions by OJK } \\
\text { which resulted in a Forced Acquisition or Hostile } \\
\text { Takeover. OJK's discretion regarding the } \\
\text { implementation of the Acquisition is not in line with } \\
\text { the Freedom of Contract Principle because the Bank } \\
\text { has independence in the implementation of the GMS } \\
\text { for the corporate agenda, the Bank is also part of a } \\
\text { Limited Liability Company that is subject to the }\end{array}$ \\
\hline
\end{tabular}




\section{Company Law so that the Optimization of Shareholders' Rights needs to be improved.}

Keywords: Bank; Acquisition; Shareholders; OJK

\section{PENDAHULUAN}

Pembangunan ekonomi merupakan sebuah proses untuk mewujudkan kemakmuran ekonomi yang berkeadilan dengan menggunakan asas gotong royong sebagaimana yang diamananatkan dalam Undang-Undang Dasar Negara Republik Indonesia Tahun 1945 sehingga dalam prosesnya selalu terjadi dinamika sistem dalam mencapai kesejahteraan bagi masyarakat, salah satunya sistem perdagangan atau bisnis. Dinamika sistem perdagangan atau bisnis untuk memperoleh keuntungan (profit) bagi perusahaan ataupun perseorangan sebagai pelaku usaha telah mengalami berbagai perubahan yang signifikan dalam melakukan ekspansi bisnis. Dinamika yang terjadi dalam melakukan ekspansi bisnis harus dilakukan berlandaskan dengan aturan Hukum yang dapat menertibkan dan memberikan kepastian antara hak dan kewajiban bagi para pihak yang melakukan ekspansi bisnis dalam rangka penguatan pembangunan ekonomi. Salah satu tindakan korporasi terkait ekspansi bisnis yaitu Restrukturisasi Perusahaan. Restrukturisasi perusahaan antara lain dengan tiga perbuatan hukum, yaitu akuisisi, merger dan konsolidasi. Terkadang dalam praktek hukum dan praktek bisnis, untuk seluruh tiga perbuatan hukum tersebut disebut saja dengan istilah "Merger dan Akuisisi" yang sering disingkat dengan $M \& \mathrm{~A}^{1}$. Akuisisi atau Pengambilalihan adalah pengambilalihan saham yang mengakibatkan beralihnya pengendalian terhadap perseroan tersebut. Perusahaan pengakuisisi biasanya perusahaan besar yang memiliki dana yang kuat, manajemen yang baik, dan jaringan yang luas, serta terkelompok dalam konglomerasi.

Dalam tataran hukum perusahaan, perseroan terbatas sebagai badan hukum baik yang sudah Go Public ataupun yang belum, segala tindakan korporasi wajib patuh terhadap UndangUndang Nomor 40 Tahun 2007 Tentang Perseroan Terbatas (“UUPT") dan ketika Perusahaan tersebut sudah tercatat dalam Bursa Efek Indonesia maka wajib pula mematuhi dan mengimplementasikan Undang-Undang Nomor 8 Tahun 1995 Tentang Pasar Modal ("UUPM"). Adanya pemisahan antara harta kekayaan pribadi dengan harta kekayaan perusahaan dalam organ perseroan memiliki struktur yang tersistem dalam kepengurusan dimulai dari adanya Rapat Umum Pemegang Saham ("RUPS"), Direksi dan Komisaris yang masing-masing memiliki berbagai macam hak dan kewajibannya dalam menjalankan tugasnya dengan itikad baik tanpa menentang aturan hukum yang berlaku untuk keberlangsungan bisnis Perusahaan.

Berdasarkan Pasal 19 UUPT j.o. Pasal 1 POJK Nomor 32 /POJK.04/2014 Tahun 2014 Tentang Rencana Penyelenggaraan RUPS Perusahaan Terbuka, RUPS mempunyai wewenang yang tidak diberikan kepada Direksi dan Dewan Komisaris, dalam batas yang ditentukan dalam UUPT dan/atau Anggaran Dasar. RUPS adalah rapat yang diselenggarakan oleh direksi Perseroan Terbatas setiap tahun dan setiap waktu berdasarkan kepentingan Perseroan Terbatas

\footnotetext{
${ }^{1}$ Munir Fuady, Hukum Tentang Akuisisi, Take Over dan LBO, Jakarta: PT Citra Aditya Bakti, 2001, hlm. 4-5.
} 
ataupun atas permintaan pemegang saham sesuai dengan ketentuan Anggaran Dasar Perseroan Terbatas. RUPS mempunyai 3 (tiga) fungsi penting, yaitu: ${ }^{2}$

1. Untuk memberitahukan atau melaporkan kepada pemegang saham tentang kinerja keuangan perusahaan.

2. Untuk mendapatkan persetujuan dari pemegang saham berkaitan dengan hal yang berada di luar kewenangan seperti pemberhentian direktur.

3. Sebagai forum diskusi antara direksi dengan pemegang saham.

RUPS terdiri dari RUPS tahunan dan RUPS lainnya atau disebut juga RUPS Luar biasa (RUPSLB) ${ }^{3}$. RUPS tahunan diadakan dalam jangka waktu 6 (enam) bulan setelah tahun buku perseroan tersebut berakhir, agendanya antara lain melakukan pengesahan laporan keuangan perseroan, sedangkan RUPSLB dapat diadakan setiap waktu berdasarkan kebutuhan untuk kepentingan perseroan. Pengambilan keputusan dalam RUPS dilakukan secara musyawarah dan mufakat sesuai dengan kuorum yang telah ditetapkan undang-undang. Akuisisi dapat terjadi secara paksa (unfriendly takeover/ hostile take over) dan sukarela/ ramah (friendly take over), yang dimaksud dengan akuisisi secara terpaksa adalah usaha pengambilalihan yang ditolak keras oleh perusahaan target.

Salah satu yang menarik diantara terjadinya Hostile Takeover yakni PT Bank Bukopin, Tbk yang terakuisisi oleh Kookmin Bank sehingga memiliki saham sebesar 67\% dan menjadi pegendali penuh atas PT Bank Bukopin, Tbk. Proses pengambilalihan saham Bank Bukopin oleh Kookmin Bank diawali dengan adanya Penawaran Umum Terbatas (PUT) V pada Juni 2020 melalui Right Issue atau Penambahan Modal dengan Hak Memesan Efek Terlebih Dahulu. Kookmin Bank menjadi standby buyer sehingga kepemilikan saham melesat dari sekitar 22\% menjadi 33,9\% membuat KB Kookmin Bank resmi menjadi Pemegang Saham Pengendali (PSP). Berdasarkan Surat Edaran Otoritas Jasa Keuangan Nomor 39 /SEOJK.03/2016 Tentang Penilaian Kemampuan Dan Kepatutan Bagi Calon Pemegang Saham Pengendali, Calon Anggota Direksi Dan Calon Anggota Dewan Komisaris yang menyatakan bahwa PSP adalah Badan hukum, orang perseorangan dan/atau kelompok usaha yang:

1. Memiliki saham perusahaan atau Bank sebesar 25\% (dua puluh lima persen) atau lebih dari jumlah saham yang dikeluarkan dan mempunyai hak suara.

2. Memiliki saham perusahaan atau Bank kurang dari $25 \%$ (dua puluh lima persen) dari jumlah saham yang dikeluarkan dan mempunyai hak suara namun yang bersangkutan dapat dibuktikan telah melakukan pengendalian perusahaan atau Bank, baik secara langsung maupun tidak langsung.

Bank Bukopin kembali melakukan penggalangan dana dengan private placement. $^{4}$ Proses private placement tersebut melibatkan Otoritas Jasa Keuangan (OJK) dengan memberikan kuasa kepada PT Bank BRI Tbk sebagai technical assistance dalam rangka

\footnotetext{
${ }^{2}$ Abe de Jong, et.al., "Shareholder's Voting at General Meeting: Evidence form the Netherlands", dalam Robert Prayoko, Doktrin Business Judgement Rule: Aplikasinya Dalam Hukum Perusahaan Modern, Yogyakarta: Graha Ilmu, 2015, hlm. 120

${ }^{3}$ Lihat penjelasan Pasal 78 ayat (1) UUPT

${ }^{4}$ https://www.cnbcindonesia.com/market/20200827160422-17-182507/bos-bosowa-ada-indikasi-hostiletakeover-bukopin (diakses pada tanggal 7 September 2020).
} 
menyelamatkan kinerja dan meningkatkan likuiditas Bank Bukopin berdasarkan kewenangan OJK dalam Pasal 9 Undang-Undang Nomor 21 Tahun 2011 Tentang Otoritas Jasa Keuangan ("UUOJK") j.o. Pasal 19 ayat (1) Undang-Undang Nomor 9 Tahun 2016 Pencegahan Dan Penanganan Krisis Sistem Keuangan dengan memerintahkan PT Bosowa Corporindo menandatangani Letter of Undertaking (LoU) yang berisikan Bosowa Corporindo memberikan kuasa kepada technical assistance sebagai pihak yang mewakili PT Bosowa Corporindo dalam RUPSLB dan dapat memberikan persetujuan terhadap pelaksanaan private placement yang ditujukan kepada KB Kookmin Bank.

Bosowa Corporindo menolak untuk menandatangani karena masih memiliki kepemilikan saham sebesar 23\% yang masih berstatus Pemegang Saham Pengendali bersama KB Kookmin Bank, memiliki hak suara dalam RUPSLB terkait pelaksanaan private placement sebagaimana yang diatur dalam UUPT. Pasal 62 ayat (1) UUPT menyatakan secara jelas bahwa setiap pemegang saham berhak meminta kepada perseroan agar sahamnya dapat dibeli dengan harga yang wajar apabila yang bersangkutan tidak menyetujui tindakan perseroan yang merugikan pemegang saham atau perseroan, berupa tindakan : a. perubahan anggaran dasar; b. pengalihan atau penjaminan kekayaan Perseroan yang mempunyai nilai lebih dari 50\% (lima puluh persen) kekayaan bersih Perseroan; atau c. penggabungan, peleburan, pengambilalihan, atau pemisahan.

Dalam RUPSLB, 25 Agustus 2020, Bosowa tidak dapat mengikuti RUPSLB berdasarkan Surat Keputusan Dewan Komisioner OJK 64/Kdk.03/2020, Bosowa Corporindo dinyatakan tidak memiliki Hak Suara dan harus melepaskan kepemilikan sahamnya kepada pihak lain karena tidak lulus penilaian kembali bagi pihak utama lembaga jasa keuangan oleh OJK. OJK menilai bahwa Bosowa Corporindo mempunyai permasalahan Integritas yang diantaranya tidak menjalankan Perintah OJK untuk menyetujui proses private placement agar KB Kookmin dapat menyuntikan modal dan kelayakan keuangan yang disebabkan dana yang digunakan untuk pembelian saham pada PUT V tidak memenuhi kriteria untuk lulus dalam Pasal 4 POJK No. 34/ POJK.03/ 2018 Tentang Penilaian Kembali Bagi Pihak Utama Lembaga Jasa Keuangan.

Hasil RUPSLB menyatakan bahwa KB Kookmin Bank berhak untuk memperbesar kepemilikan hingga 67\% melalui skema private placement dan menjadikannya sebagai pemegang saham pengendali Perseroan. Hal ini membuat Bosowa Corporindo hanya memiliki kepemilikan saham sebesar 11, 66\% dan tidak lulus menjadi menjadi pemegang saham pengendali. Bosowa Corporindo akhirnya melayangkan gugatan perbuatan melawan hukum terhadap Otoritas Jasa Keuangan di Pengadilan Negeri Jakarta Pusat akibat keputusan OJK yang merugikan pemegang saham dan melanggar hak-hak pemegang saham yang tercantum dalam UUPT. gugatan tersebut memiliki nomor perkara 693/Pdt.G/2020/PN Jkt.Pst. tertanggal 25 November 2020. Adapun, petitum yang diajukan untuk menyatakan OJK dan KB Kookmin Bank telah melakukan perbuatan melawan hukum yang mengakibatkan Bosowa Corporindo merugi secara materiil maupun immateriil.

Dalam perkara Bosowa Corporindo dengan OJK atas akuisisi PT Bank Bukopin Tbk, OJK sebagai pemegang otoritas berperan dalam proses Hostile Takeover yang menganulir hak suara Pemegang Saham. Ketentuan dalam Pasal 53 Undang-Undang Nomor 21 Tahun 2011 Tentang Otoritas Jasa Keuangan yang menegaskan sanksi pidana bagi setiap orang yang 
dengan sengaja mengabaikan, tidak memenuhi, atau menghambat pelaksanaan kewenangan OJK menjadi dilematika antara Hak Pemegang Saham yang dijamin dalam UUPT dengan kewenangan OJK dalam pelaksanaan restrukturisasi lembaga jasa keuangan Bank.

Artikel ini ditujukan untuk mengkaji kewenangan OJK terhadap Akuisisi Lembaga Jasa Keuangan Bank di masa Pandemi Covid-19 ditinjau dari Hukum Perusahaan dan solusi dalam mengoptimalisasikan hak Pemegang saham atas kewenangan OJK terhadap Lembaga Jasa Keuangan Bank di masa Pandemi Covid-19. Penulisan artikel ini akan membahas optimalisasi hak pemegang saham atas kewenangan OJK dalam pelaksanaan Akuisisi Lembaga Jasa Keuangan Bank di masa Pandemi COVID-19 dalam rangka memberikan perlindungan dan kepastian hukum bagi pemegang saham. Metode yang digunakan penulis dalam penelitian ini adalah penelitian yuridis normatif. Penelitian yuridis normatif adalah penelitian yang dilakukan dengan mengacu pada norma hukum yang terdapat pada peraturan perundang-undangan dan putusan pengadilan serta norma-norma yang berlaku di masyarakat atau juga yang menyangkut kebiasaan yang berlaku di masyarakat. Mengingat pada penelitian ini menggunakan tipe penelitian normatif dengan menggunakan pendekatan Yuridis Normatif, maka pendekatan yang digunakan dalam penelitian ini adalah pendekatan perundang-undangan (Statue Approach) dan pendekatan konseptual (Conceptual Approach). Pendekatan ini digunakan untuk memberikan konklusi hasil penelitian.

\section{PEMBAHASAN}

\section{Hak Pemegang Saham Ditinjau dari Hukum Perusahaan}

Problematika yang terjadi berdasarkan paparan dalam pendahuluan secara eksplisit telah menegaskan pentingnya ketepatan dalam memformulasikan suatu kebijakan oleh Pemegang Otoritas dalam melakukan intervensi terhadap pelaksanaan Restrukturisasi baik melalui Merger, Akuisisi, Konsolidasi dan segala bentuk restrukturisasi lainnya yang diatur sedemikian rupa dalam Undang-Undang No. 40 Tahun 2007 Tentang Perseroan Terbatas (“UUPT") sebagai Umbrella act dalam mengelola Perusahaan berbentuk PT. dalam UUPT terkandung didalamnya sebuah prinsip umum yang dikenal dengan istilah Good Corporate Governance (GCG). Prinsip GCG diakomodir oleh Perusahaan seluruh belahan dunia dan didukung oleh beberapa lembaga-lembaga internasional seperti: World Bank, IMF, OECD, dan APEC, yang menyusun beberapa prinsip umum dalam rangka mencapai tujuan penyelenggaraan Perusahaan yang fairness, transparancy, accountability, serta responsiveness ${ }^{5}$.

Fairness mensyaratkan adanya keadilan dan kesetaraan di dalam memenuhi hak-hak stakeholder yang timbul berdasarkan perjanjian dan peraturan perundang-undangan yang berlaku. Transparancy mensyaratkan keterbukaan dalam melaksanakan proses pengambilan keputusan dan keterbukaan dalam mengemukakan informasi materiil dan relevan mengenai perusahaan. Acountability, mensyaratkan adanya kejelasan fungsi, pelaksanaan, dan pertanggungjawaban organ sehingga pengelolaan perusahaan terlaksana secara efektif.

\footnotetext{
${ }^{5}$ Indria Kinasih Khameswary, "Good Corporate Goverernance dan Kurang Efektifnya Direktur Independen di Indonesia”, Jurnal Gema Keadilan, Volume 6, Edisi II, Juni 2019, hlm. 110.
} 
Responsiveness, mensyaratkan kesesuaian di dalam pengelolaan perusahaan terhadap peraturan perundang-undangan yang berlaku dan prinsip korporasi ${ }^{6}$.

Organ perseroan dalam hal ini mempunyai peran penting dalam pelaksanaan GCG secara efektif. Menurut Pasal 1 angka 2 UUPT, Organ perseroan terdiri dari Rapat Umum Pemegang Saham ("RUPS"), Direksi dan Dewan Komisaris. RUPS adalah organ perseroan yang mempunyai wewenang yang tidak diberikan kepada direksi atau dewan komisaris dalam batas yang ditentukan dalam UUPT dan/ atau anggaran dasar. RUPS merupakan organ Perseroan yang mewakili kepentingan seluruh para pemegang saham. Beberapa kewenangan pemegang saham diantaranya yaitu: ${ }^{7}$

1. Menghadiri dan mengeluarkan hak suara untuk mengambil keputusan dalam RUPS, menerima pembagian dividen dan sisa kekayaan dalam proses likuidasi;

2. Melihat daftar khusus dan daftar pemegang saham yang disediakan ditempat kedudukan Perseroan;

3. Menawarkan saham yang dimilikinya kepada pemegang saham tertentu, atau pihak lain sepanjang tidak bertentangan dengan ketentuan yang berlaku dan anggaran dasar Perseroan;

4. Mempertahankan saham yang dimilikinya terhadap setiap orang oleh karena kepemilikan saham sebagai benda bergerak memberikan hak kebendaan kepada pemiliknya. Hak kebendaan tersebut dapat dipertahankan pada setiap orang;

5. Pemegang saham berhak untuk mengajukan gugatan kepada Pengadilan apabila: Tindakan Perseroan merugikan pemegang saham dan dianggap tidak adil serta tanpa alasan yang wajar sebagai akibat keputusan RUPS, Direksi atau Dewan Komisaris;

6. Adanya tindakan Direksi yang menimbulkan kerugian kepada Perseroan yang disebabkan oleh kesalahan atau kelalaian anggota Direksi tersebut;

7. Adanya tindakan Dewan Komisaris yang menimbulkan kerugian kepada Perseroan yang disebabkan oleh kesalahan atau kelalaian anggota Dewan Komisaris tersebut;

8. Meminta Perseroan agar sahamnya dibeli dengan harga yang wajar, apabila pemegang saham tersebut tidak menyetujui tindakan Perseroan yang dianggapnya merugikan pemegang saham dan Perseroan, yang berupa: i. perubahan anggaran dasar; ii. pengalihan atau penjaminan kekayaan Perseroan yang mempunyai nilai lebih dari $50 \%$ (lima puluh persen) kekayaan bersih Perseroan; atau iii. penggabungan, peleburan, pengambilalihan, atau pemisahan;

9. Berhak untuk memperoleh dividen dalam hal Perseroan memperoleh laba bersih, sepanjang RUPS tidak menentukan lain;

10. Memperoleh keterangan yang berkaitan dengan Perseroan dari Direksi dan/atau Dewan Komisaris, sepanjang berhubungan dengan mata acara rapat dan tidak bertentangan dengan kepentingan Perseroan;

11. Memeriksa daftar pemegang saham, daftar khusus, risalah RUPS dan laporan tahunan, serta mendapatkan salinan risalah RUPS dan salinan laporan tahunan.

Maka secara eksplisit, pemegang saham hakikatnya mempunyai independensi bersuara dan memiliki hak kebendaan yang melekat dalam RUPS sebesar saham yang dimiliki. Ketika suatu perusahaan berbentuk PT hendak melakukan pemulihan dengan melakukan

\footnotetext{
${ }^{6}$ Diana Fajarwati, Analisis Penerapan Prinsip - Prinsip Good corporate Governance di Lingkungan Internal Perusahaan Umum Badan Urusan Logistik (Perum Bulog), Skripsi dari Fakultas Ilmu Sosial dan Politik Universitas Indonesia, 2011, hlm. 34

${ }^{7}$ Binoto Nadapdap, Hukum Perseroan Terbatas, Jakarta: Jala Permata Aksara, 2018, hlm. 168
} 
Restrukturisasi melalui mekanisme penambahan modal maka sebagaimana yang diamanatkan dalam Pasal 41 ayat (2) UUPT menyatakan bahwa penambahan modal perseroan dilakukan berdasarkan persetujuan RUPS. Lebih lanjut bahwa dalam Pasal 43 ayat (1) dan (2) UUPT juga menyatakan bahwa seluruh saham yang dikeluarkan untuk penambahan modal harus terlebih dahulu ditawarkan kepada setiap pemegang saham seimbang dengan pemilikan saham untuk klasifikasi saham yang sama. Dalam hal saham yang akan dikeluarkan untuk penambahan modal merupakan saham yang klasifikasinya belum pernah dikeluarkan, yang berhak membeli terlebih dahulu adalah seluruh pemegang saham sesuai dengan perimbangan jumlah saham yang dimilikinya. Ketentuan tersebut dikenal dengan istilah pre-emptive right yang kemudian menjadi dasar dalam pelaksanaan Penambahan Modal.

Pre-emptive right berlaku pula bagi perusahaan/ perseroan terbatas terbuka ("PT, Tbk"). Pasal 1 angka 7 UUPT menyatakan bahwa Perseroan Terbatas Terbuka adalah Perseroan publik atau perseroan yang melakukan penawaran umum saham, sesuai dengan ketentuan peraturan perundang-undangan di bidang pasar modal yang artinya segala kegiatan usaha berbentuk PT, Tbk wajib menerapkan Prinsip Ketebukaan Informasi. pre-emptive right juga menjadi acuan dasar dalam pelaksanaan penambahan modal oleh PT, Tbk melalui Hak Memesan Efek Terlebih Dahulu ("HMETD”) yang dimana apabila pemegang saham tidak dapat membeli saham baru yang diterbitkan maka akan mengalami risiko dilusi atas persentase kepemilikan saham yang disetorkan sebelumnya pada perusahaan. Aturan mengenai HMETD diatur secara rinci dalam POJK Nomor 14/POJK.04/2019 Tahun 2019 Tentang Perubahan atas POJK Nomor 32/POJK.04/2015 Tentang Penambahan Modal Perusahaan Terbuka Dengan Memberikan Hak Memesan Efek Terlebih Dahulu atau biasanya dikenal "PMDHMETD".

Prinsip Keterbukaan Informasi menurut Pasal 1 angka 25 UUPM yaitu pedoman umum yang mensyaratkan emiten, perusahaan publik dan pihak lain yang tunduk pada UndangUndang ini adalah untuk menginformasikan kepada masyarakat dalam waktu yang tepat seluruh informasi materil mengenai usahanya atau efeknya yang dapat berpengaruh terhadap keputusan pemodal terhadap efek yang dimaksud dan atau harga efek tersebut. Urgensi penerapan Prinsip Keterbukaan Informasi bagi para Pemegang Saham (shareholders) juga tercantum dalam Article 9c angka 2 Directive (EU) 2017/828 Of The European Parliament And Of The Council of 17 May 2017 yang berbunyi:

"Member States shall ensure that companies publicly announce material transactions with related parties at the latest at the time of the conclusion of the transaction. The announcement shall contain at least information on the nature of the related party relationship, the name of the related party, the date and the value of the transaction and other information necessary to assess whether or not the transaction is fair and reasonable from the perspective of the company and of the shareholders who are not a related party, including minority shareholders."

Prinsip keterbukaan informasi merupakan hal yang fundamental sehingga harus dilaksanakan oleh setiap perusahaan terbuka dengan menyusun prospektus yang baik dan jelas untuk memenuhi Hak Pemegang Saham dalam memperoleh informasi sebagaimana amanat UUPT dan UUPM. Ketika terjadi ketidakadilan dalam keputusan RUPS dan bilamana kepengurusan perseroan dalam hal ini yang berwenang adalah Direksi dan Dewan Komisaris tidak mengimplementasikan prinsip fiduciary duties yang mengakibatkan perusahaan merugi 
hingga kemungkinan terburuk berujung permohonan pailit ke Pengadilan sehingga berpengaruh secara signifikan terhadap kontinuitas perusahaan serta penurunan nilai dividen saham ataupun terjadinya gagal bayar atas bunga obligasi yang disepakati dalam prospektus terhadap para Investor maka Pemegang saham sebagai Investor memiliki Hak untuk menggugat perseroan di Pengadilan sebagaimana yang tercantum dalam Pasal 61 ayat (1) dan ayat (2) UUPT yang berbunyi:

"Setiap pemegang saham berhak mengajukan gugatan terhadap Perseroan ke Pengadilan Negeri apabila dirugikan karena tindakan Perseroan yang dianggap tidak adil dan tanpa alasan wajar akibat dari keputusan RUPS, Direksi, dan/ atau Dewan Komisaris. Gugatan tersebut diajukan ke Pengadilan Negeri yang daerah hukumnya meliputi tempat kedudukan Perseroan”.

\section{Kewenangan OJK dalam Akuisisi Lembaga Jasa Keuangan Bank}

Pasal 1 angka 1 Undang-Undang Nomor 7 Tahun 1992 Tentang Perbankan sebagaimana telah diubah dengan Undang-Undang Nomor 10 Tahun 1998 (“UU Perbankan") Perbankan mengatakan bahwa Perbankan adalah segala sesuatu yang menyangkut tentang Bank, mencakup kelembagaan, kegiatan usaha, serta cara dan proses dalam melaksanakan kegiatan usahanya. Sedangkan pengertian Bank dijelaskan dalam Pasal 1 angka 2 UU Perbankan yaitu badan usaha yang menghimpun dana dari masyarakat dalam bentuk simpanan dan menyalurkannya kepada masyarakat dalam bentuk kredit dan. Atau bentuk-bentuk lainnya dalam rangka meningkatkan taraf hidup banyak. Maka dengan pengertian diatas dapat disimpulkan, segala sesuatu yang berhubungan dengan Bank berarti berhubungan dan menghubungkan dengan orang banyak, dalam hal ini terdapat komponen penting didalamnya yaitu, Nasabah, Pengelola Bank, dan Otoritas yang diamanatkan oleh Pemerintah untuk mengawasi, menyusun kebijakan dan menindak bilamana tidak sesuai dengan prosedur Hukum yang berlaku.

Pengawasan Perbankan pada prinsipnya terbagi dalam dua jenis, yaitu, macroeconomic supervision dan prudential supervision. Adapun pemahaman dari kedua hal tersebut adalah:

1. Macro-economic supervision adalah pengawasan dalam rangka mendorong bankbank untuk ikut menunjang pertumbuhan ekonomi dan menjaga kestabilan moneter.

2. Prudential supervision adalah pengawasan yang mendorong bank secara individual tetap sehat serta mampu memelihara kepentingan masyarakat secara baik ${ }^{8}$.

Tujuan yang ingin dicapai oleh macroprudential supervision adalah mengarahkan dan mendorong bank serta sekaligus mengawasinya, agar dapat berperan dalam berbagai program pencapaian sasaran ekonomi makro. Sedangkan tujuan prudential supervision adalah mengupayakan agar setiap bank secara individual sehat dan aman, serta seluruh industri perbankan sehat, sehingga kepercayaan masyarakat dapat terjaga. Lembaga Bank memang perlu dipagari dengan berbagai peraturan yang membatasi atau sekurang-kurangnya

\footnotetext{
${ }^{8}$ Rebekka Dosma Sinaga, et al., "Sistem Koordinasi Antara Bank Indonesia Dan Otoritas Jasa Keuangan Dalam Pengawasan Bank Setelah Lahirnya Undang-Undang Nomor 21 Tahun 2011 Tentang Otoritas Jasa Keuangan", Transparency Journal of Economic, Volume 1 No. 2, 2002, hlm. 4.
} 
mengingatkan mengenai perlunya penanganan risiko secara seksama, dan bahkan jika perlu melarang bank melakukan kegiatan tertentu yang mengandung risiko tinggi ${ }^{9}$.

Dahulu sebelum OJK diberikan mandat untuk berwenang dalam melakukan segala tindakan pengawasan, pencegahan dan penindakan apabila ditemukan indikasi buruknya likuditas suatu Bank sehingga dapat mengkibatkan terganggunya perekenomian nasional dalam bidang perbankan, Bank Indonesia dapat meminta diadakannya suatu Pengambilalihan/ Akuisisi terhadap Lembaga Jasa Keuangan Bank dan dapat memberikan izin terhadap pelaksanaan Akuisisi melalui pimpinan Bank Indonesia sebagaimana yang tercantum dalam Undang-Undang Nomor 7 Tahun 1992 Tentang Perbankan sebagaimana telah diubah dengan Undang-Undang Nomor 10 Tahun 1998 j.o. Peraturan Pemerintah Republik Indonesia Nomor 28 Tahun 1999 Tentang Merger, Konsolidasi Dan Akuisisi Bank.

Dengan lahirnya Undang-Undang Nomor 21 Tahun 2011 Tentang Otoritas Jasa Keuangan ("UU OJK"), OJK mempunyai wewenang mengatur dan mengawasi kelembagaan bank yang meliputi perizinan untuk pendirian bank, pembukaan kantor bank, anggaran dasar, rencana kerja, kepemilikan, kepengerusan dan sumber daya manusia, merger, konsolidasi dan akuisisi bank, serta pencabutan izin usaha bank. pada Pasal 7 UU OJK, kewenangan OJK juga meliputi penilaian tingkat kesehatan bank seperti likuiditas, rentabilitas, solvabilitas, kualitas aset, rasio kecukupan modal minimum, batas maksimum pemberian kredit (BMPK) sampai pencadangan Bank. hal ini mengakibatkan beralihnya pengawasan terhadap lembaga keuangan dari Bank Indonesia ke OJK.

Pemisahan dan Peralihan otoritas juga terjadi di negara Jerman. Jerman awalnya menetapkan The Deutsche Bundesbank sebagai badan pengawas keuangan baik di bidang Bank maupun non-Bank (Asuransi, Sekuritas dan Lembaga keuangan lainnya). Pada tanggal 22 Maret 2002 RUU tentang restrukturisasi pengawasan keuangan akhirnya disetujui dengan ditetapkannya UU tentang regulator keuangan 1 Mei 2002 yaitu Bundesanstalt für Finanzdienstleistungssaufscht (BaFin). BaFin dibentuk pada 2002, dan mengawasi lebih dari 2.000 bank, 800 lembaga jasa keuangan, dan lebih dari 700 perusahaan asuransi. Tujuan pendirian BaFin adalah menciptakan satu regulator yang mengawasi dan mengatur seluruh industri keuangan ${ }^{10}$.

Salah satu indikator keberhasilan bagi Bank yaitu Bank tersebut mengimplementasikan prudential principle dengan maksimal sehingga Bank mendapatkan predikat "trusted" dari masyarakat sebagai Nasabah apalagi di masa pandemic COVID-19 yang dapat menghambat mobilitas masyarakat sehingga selalu terhubung dengan dunia digital, dalam hal ini perbankan telah menyediakan berbagai macam fitur aplikasi sebagai platform bagi Nasabah dalam melakukan transaksi perbankan. Rasio kecukupan Modal (“Capital Adequacy Ratio/CAR”) harus terjaga agar likuiditas Bank tidak terganggu, ketika likuiditas mulai terganggu, dalam rangka peningkatan dan kelancaran likuiditas biasanya Bank akan melakukan tindakan korporasi. Tindakan korporasi diantaranya berupa Merger dan Akuisisi marak dilakukan oleh Bank dimasa pandemic COVID-19 sebagai upaya menjaga kelancaran likuiditas tersebut.

\footnotetext{
9 Ahmad Solahudin, "Pemisahan Kewenangan Bank Indonesia Dengan Otoritas Jasa Keuangan Dalam Pengawasan Bank", Jurnal IUS: Kajian Hukum dan Keadilan, Volume 3, No. 7, 2015, hlm. 114.

${ }^{10}$ Agata Kocia dan Grazyna Szymansk, "PFSA and BaFin - Comparison of Institutional Framework in Dynamic Financial Markets”, Journal of Applied Business and Economics, Volume 13 No. 2, 2012, hlm. 196-199
} 
contoh beberapa Bank yang melakukan Merger ataupun Akuisisi pada masa pandemic COVID19 yaitu: Akuisisi Bank Bukopin oleh KB Kookmin Bank asal Korea Selatan, Merger 3 (Tiga) Bank Syariah Indonesia yakni BRI Syariah, Bank Mandiri Syariah dan BNI Syariah, Akuisisi Bank BKE oleh Sea Group asal Singapura, dan Akuisisi Bank Harda International oleh Mega Corpora asal Indonesia.

Berdasarkan POJK 41/POJK.03/2019 tentang Penggabungan, Peleburan, Pengambilalihan, Integrasi, dan Konversi Bank Umum, OJK mempunyai kewenangan penuh dalam memberikan izin tertulis dan melakukan fit \& proper Test pada calon Pemegang Saham Pengendali. Dalam pelaksanaan Akuisisi (Pengambilalihan) sebagaimana yang tercantum dalam Pasal 28 POJK 41/POJK.03/2019 tentang Penggabungan, Peleburan, Pengambilalihan, Integrasi, dan Konversi Bank Umum mengatakan:

“(1) OJK melakukan penelaahan terhadap dokumen persiapan pelaksanaan Pengambilalihan sebagaimana dimaksud dalam Pasal 27, paling lama 20 (dua puluh) hari kerja sejak dokumen diterima secara lengkap.

(2) Dalam melakukan penelaahan sebagaimana dimaksud pada ayat (1), OJK melakukan: a. penelitian atas kelengkapan dan kebenaran dokumen sebagaimana dimaksud dalam Pasal 27 ayat (2); dan b. penilaian kemampuan dan kepatutan terhadap calon PSP sebagai pihak yang akan mengambil alih Bank termasuk penelitian sumber dana yang digunakan untuk mengambil alih Bank.

(3) Dalam melakukan penelaahan sebagaimana dimaksud pada ayat (1), OJK dapat meminta dokumen dan/atau informasi tambahan kepada Bank yang diambil alih dan/atau pihak yang mengambil alih."

Dalam hal OJK memberikan persetujuan atas permohonan izin Pengambilalihan, OJK menetapkan hasil penilaian kemampuan dan kepatutan terhadap pihak yang akan mengambil alih. Dalam POJK 41/POJK.03/2019 tidak diatur secara rinci apa saja yang menjadi indikator kelulusan penilaian kemampuan dan kepatutan terhadap pihak yang akan mengambil alih dan menjadi pengendali, tetapi dalam Pasal 4 POJK Nomor 34 /POJK.03/2018 Tentang Penilaian Kembali Bagi Pihak Utama Lembaga Jasa Keuangan diatur yakni:

1. Tindakan-tindakan baik secara langsung dan tidak langsung berupa:

a. Memengaruhi dan/atau menyuruh Pihak Utama Pengurus, Pihak Utama Pejabat, dan/atau pegawai Lembaga Jasa Keuangan ("LJK") untuk menyembunyikan dan/atau mengaburkan pelanggaran dari suatu ketentuan atau kondisi keuangan dan/atau transaksi yang sebenarnya;

b. Memengaruhi dan/atau menyuruh Pihak Utama Pengurus, Pihak Utama Pejabat, dan/atau pegawai LJK untuk memberikan keuntungan secara tidak wajar kepada pemegang saham, Pihak Utama, pegawai LJK, dan/atau pihak lain yang dapat merugikan atau mengurangi keuntungan LJK;

c. Memengaruhi dan/atau menyuruh Pihak Utama Pengurus, Pihak Utama Pejabat, dan/atau pegawai LJK untuk melakukan perbuatan yang melanggar prinsip kehatihatian di sektor jasa keuangan dan/atau prinsip pengelolaan LJK yang baik; dan/atau

d. Memengaruhi dan/atau menyuruh Pihak Utama Pengurus, Pihak Utama Pejabat, dan/atau pegawai LJK yang menjalankan kegiatan usaha berdasarkan prinsip 
syariah untuk melakukan perbuatan yang melanggar prinsip syariah di sektor jasa keuangan syariah;

2. Terbukti melakukan tindak pidana yang telah diputus oleh pengadilan dan mempunyai kekuatan hukum tetap sebagaimana dimaksud dalam Peraturan Otoritas Jasa Keuangan mengenai penilaian kemampuan dan kepatutan bagi pihak utama lembaga jasa keuangan;

3. Menyebabkan LJK mengalami kesulitan yang membahayakan kelangsungan usaha LJK dan/atau dapat membahayakan industri jasa keuangan

4. Tidak melaksanakan perintah Otoritas Jasa Keuangan untuk melakukan dan/atau tidak melakukan tindakan tertentu;

5. Memiliki kredit dan/atau pembiayaan macet di LJK dan/atau menjadi pengendali, anggota direksi, anggota dewan komisaris, atau yang setara dari perusahaan yang mempunyai kredit dan/atau pembiayaan macet.

6. Terbukti dinyatakan pailit dan/atau menjadi pemegang saham, anggota direksi, anggota dewan komisaris, atau yang setara, yang dinyatakan bersalah menyebabkan suatu perusahaan dinyatakan pailit atau dicabut izin usahanya;

7. Tidak melakukan upaya yang diperlukan pada saat LJK menghadapi kesulitan permodalan dan/atau likuiditas; dan/atau

8. Menolak memberikan komitmen dan/atau tidak memenuhi komitmen yang telah disepakati dengan Otoritas Jasa Keuangan dan/atau pemerintah.

Kewenangan OJK menjadi semakin masif pasca Pemerintah mengeluarkan PERPPU Nomor 1 Tahun 2020 Tentang Kebijakan Keuangan Negara Dan Stabilitas Sistem Keuangan Untuk Penanganan Pandemi Corona Virus Disease 2019 (COVID-19) Dan/Atau Dalam Rangka Menghadapi Ancaman Yang Membahayakan Perekonomian Nasional Dan/Atau Stabilitas Sistem Keuangan. Lahirnya PERPPU tersebut diantaranya karena memburuknya sistem keuangan yang ditunjukkan dengan penurunan berbagai aktivitas ekonomi domestik sehingga perlu dimitigasi bersama oleh Pemerintah dan Komite Stabilitas Sistem Keuangan ("KSSK") untuk melakukan tindakan antisipasi (forward looking) dalam rangka menjaga stabilitas sektor keuangan. Untuk mendukung pelaksanaan kewenangan KSSK dalam rangka penanganan permasalahan stabilitas sistem keuangan, sebagaimana dalam Pasal 23 ayat (1) PERPPU Nomor 1 Tahun 2020, OJK berwenang untuk:

1. memberikan perintah tertulis kepada lembaga jasa keuangan untuk melakukan penggabungan, peleburan, pengambilalihan, integrasi dan/atau konversi;

2. menetapkan pengecualian bagi pihak tertentu dari kewajiban melakukan prinsip keterbukaan di bidang pasar modal dalam rangka pencegahan dan penanganan krisis sistem keuangan; dan

3. menetapkan ketentuan mengenai pemanfaatan teknologi informasi dalam penyelenggaraan Rapat Umum Pemegang Saham atau rapat lain yang berdasarkan ketentuan peraturan perundangundangan wajib dilakukan oleh pelaku industri jasa keuangan. 
Selain melakukan penilaian mengenai pemenuhan persyaratan/kecukupan solvabilitas dan tingkat kesehatan Bank, OJK dapat memaksa pihak Lembaga Jasa Keuangan Bank untuk melakukan penggabungan, peleburan, pengambilalihan, Integrasi dan/atau konversi. Tetapi, yang menjadi Indikator Bank jenis apa yang dapat diberikan perintah tertulis oleh OJK untuk melakukan tindakan Korporasi tersebut masih belum jelas, dalam PERPPU dikatakan yang dapat menjadi indikator yakni jenis Bank Sistemik tetapi juga dicantumkan Bank selain Bank Sistemik. Menurut Pasal 1 Angka 5 Undang-Undang Nomor 9 Tahun 2016 Tentang Pencegahan Dan Penanganan Krisis Sistem Keuangan Bank Sistemik adalah Bank yang karena ukuran aset, modal, dan kewajiban; luas jaringan atau kompleksitas transaksi atas jasa perbankan; serta keterkaitan dengan sektor keuangan lain dapat mengakibatkan gagalnya sebagian atau keseluruhan Bank lain atau sektor jasa keuangan, baik secara operasional maupun finansial, jika Bank tersebut mengalami gangguan atau gagal.

Konsekuensi Hukum apabila tidak menjalankan perintah OJK tersebut, maka sebagaimana yang tercantum dalam dalam Pasal 53 UU OJK j.o. Pasal 26 ayat (1) dan ayat (2) PERPPU Nomor 1 Tahun 2020 Tentang Kebijakan Keuangan Negara Dan Stabilitas Sistem Keuangan Untuk Penanganan Pandemi Corona Virus Disease 2019 (COVID-19) Dan/Atau Dalam Rangka Menghadapi Ancaman Yang Membahayakan Perekonomian Nasional Dan/Atau Stabilitas Sistem Keuangan yaitu apabila setiap orang yang dengan sengaja mengabaikan, tidak memenuhi, tidak melaksanakan atau menghambat pelaksanaan kewenangan Otoritas Jasa Keuangan sebagaimana dimaksud dalam Pasal 23 ayat (1) huruf a, dipidana dengan pidana penjara paling singkat 4 (empat) tahun dan pidana denda paling sedikit Rp10.000.000.000,00 (sepuluh miliar rupiah) atau pidana penjara paling lama 12 (dua belas) tahun dan pidana denda paling banyak Rp300.000.000.000,00 (tiga ratus miliar rupiah). Apabila pelanggaran sebagaimana dimaksud pada ayat (1) dilakukan oleh korporasi, dipidana dengan pidana denda paling sedikit Rp 1.000.000.000.000,00 (satu triliun rupiah).

\section{Optimalisasi Hak Pemegang Saham Atas Kewenangan OJK Dalam Pelaksanaan Akuisisi Lembaga Jasa Keuangan Bank Pada Masa Pandemi COVID-19}

Keistimewaan kewenangan OJK sebagai otoritas yang menjalankan fungsi prudential supervision telah didukung secara masif oleh Pemerintah sebagai langkah mitigasi risiko krisis keuangan yang dapat mengancam perekenomian nasional ditengah masa pandemi COVID-19 salah satunya kewenangan untuk dapat memaksa Bank melakukan restrukturisasi berupa akuisisi yang tercantum dalam PERPPU Nomor 1 Tahun 2020 Tentang Kebijakan Keuangan Negara Dan Stabilitas Sistem Keuangan Untuk Penanganan Pandemi Corona Virus Disease 2019 (COVID-19) Dan/Atau Dalam Rangka Menghadapi Ancaman Yang Membahayakan Perekonomian Nasional Dan/Atau Stabilitas Sistem Keuangan. Perintah tertulis yang dikeluarkan apabila OJK dalam penilaiannya merasa bahwa Bank tersebut perlu dilakukan Akuisisi maka harus dilaksanakan karena adanya ancaman pidana dan denda untuk setiap orang maupun korporasi. Tetapi, ada satu hal yang dilupakan oleh Pemerintah dalam pemberian kewenangan terhadap OJK yakni bahwa Bank bagaimanapun adalah Perusahaan yang berbentuk 'Perseroan Terbatas' yang artinya tunduk pada UU PT. ketika Bank tersebut berbentuk terbuka (Tbk.) maka segala pelaksanaan Akuisisi juga harus tunduk pada UUPM. 
Ketika menyinggung Hukum Perusahaan didalamnya terdapat sektor privat yang memiliki independensi dalam melakukan Perjanjian yang menimbulkan Perikatan antar Pihak yang dimana dapat melahirkan Hak dan Kewajiban yang harus dipenuhi. Dalam UUPT, Pasal 1 angka 1 telah jelas mengatakan bahwa Perseroan Terbatas adalah Badan Hukum yang merupakan persekutuan modal, didirikan berdasarkan 'Perjanjian', melakukan kegiatan usaha dengan modal dasar yang seluruhnya terbagi dalam saham dan memenuhi persyaratan yang ditetapkan dalam Undang-Undang ini serta Peraturan Pelaksanaannya”. Dalam perjanjian juga dilandasi oleh beberapa asas, yaitu: ${ }^{11}$

1. Asas kebebasan berkontrak (freedom of contract).

Dapat dianalisa dari ketentuan Pasal 1338 ayat (1) KUH Perdata yang berbunyi "Semua perjanjian yang dibuat secara sah berlaku sebagai undang-undang bagi mereka yang membuatnya. Berdasarkan asas kebebasan berkontrak, maka orang pada asasnya dapat membuat perjanjian dengan isi yang bagaimanapun juga, asal tidak bertentangan dengan undang-undang, kesusilaan dan ketertiban umum.

2. Asas konsensualisme (concensualism).

Asas konsensualisme mempunyai arti yang terpenting, bahwa untuk melahirkan perjanjian cukup dengan sepakat saja dan bahwa perjanjian itu (dan perikatan yang ditimbulkan karenanya) sudah dilahirkan pada saat atau detik tercapainya konsensus. Asas konsensualisme dapat disimpulkan dalam Pasal 1320 ayat (1) KUH Perdata. Pada pasal tersebut ditentukan bahwa salah satu syarat sahnya perjanjian adalah adanya kata kesepakatan antara kedua belah pihak.

3. Asas pacta sunt servanda.

Baik dalam sistem terbuka yang dianut oleh hukum perjanjian ataupun bagi prinsip kekuatan mengikat, kita dapat merujuk pada Pasal 1374 ayat (1) BW (lama) atau Pasal 1338 ayat (1) KUH Perdata: "Semua persetujuan yang dibuat secara sah berlaku sebagai undang-undang bagi mereka yang membuatnya." Dengan kata lain, perjanjian yang dibuat secara sah berlaku seperti berlakunya undang-undang bagi para pihak yang membuatnya (Pasal 1338 ayat (1) dan ayat (2) KUH Perdata, maka para pihak harus mentaati apa yang telah mereka sepakati bersama.

4. Asas itikad baik (Good Faith).

Asas itikad baik merupakan salah satu asas yang dikenal dalam hukum perjanjian. Ketentuan ini diatur dalam pasal 1338 ayat (3) KUHPerdata, bahwa perjanjian harus dilaksanakan dengan itikad baik.

5. Asas kepribadian (personality).

Asas kepribadian tercantum dalam Pasal 1340 KUHPerdata: "Suatu perjanjian hanya berlaku antara pihak-pihak yang membuatnya. Suatu perjanjian tidak dapat membawa rugi kepada pihak-pihak ketiga; tak dapat pihak-pihak ketiga mendapat manfaat karenanya, selain dalam hal yang diatur dalam Pasal 1317."

Korelasi antara asas-asas hukum perjanjian dengan segala tindakan korporasi tidak dapat terhindarkan karena semua tindakan korporasi baik berupa Akuisisi, Merger, Konsolidasi dan

\footnotetext{
${ }^{11}$ Niru Anita Sinaga, "Peranan Asas-Asas Hukum Perjanjian Dalam Mewujudkan Tujuan Perjanjian”, Jurnal Bina Mulia Hukum, Volume 7 No. 2, 2018, hlm. 115-117.
} 
lainnya berawal dari perjanjian yang menimbulkan kesepakatan terlebih dahulu yakni dikenal dengan adanya Rapat Umum Pemegang Saham ("RUPS"). RUPS merupakan salah satu organ perseroan yang menjadi nahkoda kemana kapal berlabuh. para pemegang saham mempunyai kebebasan dan independensi dalam mengeluarkan suara sesuai dengan jumlah persentase saham yang dimiliki dalam perseroan terbatas pada RUPS yang dijamin dalam UUPT. kewenangan OJK yang tercantum dalam Pasal 23 ayat (1) PERPPU Nomor 1 Tahun 2020 dalam memberikan perintah tertulis tidak sejalan dengan Asas Kebebasan Berkontrak yang terdapat dalam Pasal 1338 KUHPerdata karena seharusnya diskresi yang dikeluarkan oleh OJK tidak menyentuh ranah privat dalam agenda tindakan korporasi walaupun dalam hal ini Lembaga Jasa Keuangan Bank. Bank tetap memiliki independensi tersendiri dalam menentukan segala tindakan korporasi karena Bank juga merupakan bagian dari 'perseroan terbatas' yang tunduk pada UUPT. Perintah tersebut juga disertai ancaman sanksi pidana bagi siapa saja ataupun korporasi yang tidak menjalankan perintah OJK secara jelas bersifat otoriter tentu melahirkan ketidakadilan bagi para stakeholder yang memiliki hak dalam RUPS.

Persoalan yang besar dalam merumuskan konsep keadilan terletak dalam dua wacana. Pertama soal adil dan tidak-adil sudah dari sendirinya merupakan soal nilai (yaitu mengenai apa yang baik atau tidak baik). Kedua, dalam kenyataannya keputusan untuk menentukan sesuatu sudah adil atau belum adil, sesuatu adalah adil atau tidak adil, juga ditumpukkan pada seperangkat nilai-nilai yang sama mendasarnya ${ }^{12}$. Satjipto Rahardjo antara lain menyebut kemerdekaan, persamaan, kebahagiaan dan kebenaran sebagai nilai-nilai dasar yang harus atau bisa digunakan untuk menetapkan soal adil atau tidak adil ${ }^{13}$. Maka dalam memformulasikan konsep pemecahan masalah dalam mencapai nilai keadilan seharusnya legislator mempertimbangkan keselarasan antara perlindungan bagi investor, kepentingan otoritas, dan kepentingan publik dikarenakan Bank merupakan badan usaha yang melibatkan banyak pihak sehingga tidak tepat pemecahan masalah dengan model keotoriteran dari Pemerintah yang mendelegasikan kewenangan tersebut kepada OJK yang dapat mengatur sedemikian rupa terhadap segala tindakan Bank terlebih lagi mengintervensi RUPS.

Salah satu yang menarik menjadi das sein yang dapat menjadi contoh adanya unsur ketidakadilan akibat adanya kewenangan OJK dalam Akuisisi Bank yakni terjadinya gugatan di PN Jakarta Pusat yang dilakukan oleh PT Bosowa Corporindo terhadap OJK dan KB Kookmin Bank dalam Akuisisi PT Bank Bukopin, Tbk. petitum yang diajukan yakni berupa pembatalan keabsahan RUPS dalam agenda Private Placement yang menyebabkan Bosowa Corporindo tidak berhak menjadi PSP karena OJK dalam hal ini mengintervensi pelaksanaan Akuisisi dengan memaksa PT Bosowa Corporindo menyetujui KB Kookmin Bank menjadi PSP dengan kepemilikan saham menjadi sebesar $67 \%$ melalui surat Perintah Tertulis OJK No.SR-17/D.03/2020 tanggal 10 Juni 2020 dan No. SR-28/D.03/2020 tanggal 9 Juli 2020 hal Perintah Tertulis Pemberian Kuasa Khusus kepada Tim Technical Assistance dari PT Bank Rakyat Indonesia (Persero), Tbk. dan gugatan terhadap Surat Keputusan Dewan Komisioner OJK 64/Kdk.03/2020, yang menyatakan Bosowa Corporindo tidak memiliki Hak Suara dan

\footnotetext{
${ }^{12}$ Budiono Kusumohamidjojo, Teori Hukum: Dilema antara Hukum dan Kekuasaan, Bandung: Yrama Widya, 2017, hlm. 275.

${ }^{13}$ Satjipto Rahardjo, Ilmu Hukum, Bandung: Citra Aditya, 2000, hlm. 167.
} 
harus melepaskan kepemilikan sahamnya kepada pihak lain karena tidak lulus penilaian kembali bagi pihak utama lembaga jasa keuangan oleh OJK di PTUN.

Bilamana pertimbangan OJK adalah dalam rangka menyehatkan PT Bank Bukopin sehingga memaksa Bosowa melepaskan statusnya sebagai PSP, Rasio kecukupan Modal (CAR/ Capital Adequacy Ratio) yang tercantum dalam prospektus PUT V PT Bank Bukopin adalah sebesar 12,59\% yang masih berada diatas batas minimum yakni berkisar 8\%-12\% yang diatur dalam POJK Nomor 11 /POJK.03/2016 Tentang Kewajiban Penyediaan Modal Minimum Bank Umum. Setelah pelaksanaan right issue, CAR PT Bank Bukopin naik dikisaran 15\%-16\%, tentu dari segi rasio kecukupan modal terbilang memenuhi kriteria. Pelaksanaan Private Placement justru akan merugikan Pemegang Saham karena terjadinya dilusi akibat private placement tersebut dan Bosowa terlepas statusnya sebagai PSP dan saham yang dimiliki terdilusi.

Perkara yang terjadi dalam Akuisisi PT Bank Bukopin, Tbk melahirkan adanya akuisisi secara paksa/ Hostile Takeover. Pada hostile takeover, manajemen perusahaan yang akan diambilalih tidak diajak berunding, tetapi perusahaan yang akan mengambil alih langsung menawarkan ke pemegang saham dengan persyaratan lebih menarik ${ }^{14}$. Proses Akuisisi/ Pengambilalihan didasarkan oleh RUPS yang didasari oleh kontrak/perjanjian, maka dalam pelaksanaannya harus berdasarkan syarat-syarat sahnya perjanjian yang tertuang dalam Pasal 1320 KUHPerdata yaitu: sepakat mereka yang mengikatkan dirinya, kecakapan untuk membuat suatu perikatan, suatu hal tertentu dan suatu sebab yang halal. Persyaratan tersebut diatas berkenan baik mengenai subjek maupun objek perjanjian. Persyaratan yang pertama dan kedua berkenan dengan subjek perjanjian atau syarat subjektif. Persyaratan yang ketiga dan keempat berkenan dengan objek perjanjian atau syarat objektif. Apabila syarat objektif dalam perjanjian tidak terpenuhi maka Perjanjian tersebut batal demi hukum atau perjanjian yang sejak semula sudah batal, hukum menganggap perjanjian tersebut tidak pernah ada. Apabila syarat subjektif tidak terpenuhi maka Perjanjian tersebut dapat dibatalkan.

Kewenangan OJK dalam hal ini bertentangan dengan UUPT dan UUPM sehingga membuka celah bahwa perintah tertulis oleh OJK mengakibatkan perbuatan melawan hukum dalam pelaksanaan Akuisisi yang tentu dalam hal ini merugikan pemegang saham. Dualisme kewenangan OJK dengan Hak-Hak Pemegang Saham dalam UUPT menjadi dilematika baru bagi dunia Hukum di Indonesia tetapi yang paling terpenting adalah jika Pemerintah menggunakan pendekatan Teori Investasi untuk menjaga stabilitas perekonomian nasional, maka seharusnya Otoritas hadir untuk memberikan keamanan, arahan, serta menjamin perlindungan bagi para Pemegang Saham selaku Investor bukan menunjukkan keotoriteran yang dapat menimbulkan penyelewengan kekuasaan. Menurut Abdul Halim, investasi pada hakikatnya merupakan penempatan sejumlah dana pada saat ini dengan harapan untuk memperoleh keuntungan di masa mendatang. Lebih jauh ekonom asal Amerika Paul R. Krugman dan Maurice Obstfeld mengatakan bahwa bagian output yang digunakan oleh perusahaan-perusahaan guna menghasilkan output dimasa mendatang ini bisa disebut sebagai Investasi ${ }^{15}$.

\footnotetext{
${ }^{14}$ Srilaksmi Nuri Indradewi, Op.Cit. hlm. 10.

${ }^{15}$ Steven Siaila, et al., "Studi Kelayakan Pengembangan Rumah Sakit Sumber Hidup Gereja Protestan Maluku Di Kota Ambon", Jurnal SOSOQ, Volume 7 No. 2, 2019, hlm. 75
} 
Maka dalam rangka megoptimalisasikan hak pemegang saham atas kewenangan OJK terhadap Akuisisi Bank diperlukan perlindungan hukum terhadap independensi pemegang saham dalam RUPS. Perlindungan hukum merupakan salah satu teori yang wajib diimplementasikan dalam segala proses kehidupan manusia, Fitzgerald mengutip istilah teori perlindungan hukum dari Salmond bahwa hukum bertujuan mengintegrasikan dam mengkoordinasikan berbagai kepentingan dalam masyrakat karena dalam suatu lalulintas kepentingan, perlindungan terhadap kepentingan tertentu dapat dilakukan dengan cara membatasi berbagai kepentingan di lain pihak. Kepentingan hukum adalah mengurusi hak dan kepentingan manusia, sehingga hukum memiliki otoritas tertinggi untuk menentukan kepentingan manusia yang perlu diatur dan dilindungi. Perlindungan hukum harus melihat tahapan yakni perlindungan hukum lahir dari suatu ketentuan hukum dan segala peraturan hukum yang diberikan oleh masyarakat yang pada dasarnya merupkan kesepakatan masyarakat tersebut untuk mengatur hubungan perilaku antara anggota-anggota masyarakat dan antara perseorangan dengan pemerintah yang dianggap mewakili kepentingan masyarakat ${ }^{16}$. Dalam Pasal 28 G Ayat (1) Undang-Undang Dasar 1945 menyatakan bahwa setiap orang berhak atas perlindungan diri pribadi, keluarga, kehormatan, martabat, dan harta benda dibawah kekuasaannya, serta berhak atas rasa aman dan perlindungan diri dari ancaman ketakutan untuk berbuat atau tidak berbuat sesuatu yang merupakan hak asasi.

Dalam pelaksanaan RUPS tentu Kebijakan yang dikeluarkan oleh pemerintah seharusnya memperkuat atau mengoptimalisasikan Hak-Hak Pemegang Saham disamping penguatan kewenangan OJK dalam pelaksanaan Akuisisi di LJK Bank sehingga tidak melahirkan Hostile Takeover yang tentu akan berpengaruh pada Investor yang ingin menyertakan Modalnya. Standarisasi dari sebuah unsur kegentingan yang memaksa perlu ditetapkan atau dievaluasi oleh Pemerintah sehingga Bank jenis apa yang dapat ditetapkan sebagai Bank yang harus menjalankan perintah dari OJK untuk melakukan penggabungan, peleburan, pengambilalihan, integrasi dan/atau konversi sehingga diskresi yang dikeluarkan oleh OJK tidak bersifat tendensius, dan berpotensi menyalahgunakan wewenang. Kekosongan hukum tersebut dalam menetapkan Bank jenis apa yang dapat diberikan perintah tertulis perlu diatur dalam rangka mengoptimalisasikan perlindungan bagi pemegang saham karena dalam perintah tertulis dari OJK dapat juga merugikan pemegang saham diantaranya hilangnya posisi sebagai pemegang saham pengendali ataupun pihak pemegang saham utama, mengalami risiko dilusi atas kepemilikan saham, serta ancaman sanksi pidana bagi yang tidak menjalankan perintah tertulis OJK dalam pelaksanaan akuisisi Bank. Pembatasan kewenangan OJK perlu dilakukan dalam pelaksanaan RUPS dan memperjelas ketentuan Bank yang dapat diberikan perintah tertulis sehingga memberikan perlindungan terhadap Hak Pemegang Saham dalam pelaksanaan Akuisisi Bank.

\section{PENUTUP}

Berdasarkan hasil pembahasan, dapat disimpulkan bahwa kewenangan OJK sebagai prudential supervision dalam Pelaksanaan Akuisisi Lembaga Jasa Keuangan Bank Pada Masa Pandemi COVID-19 yang tercantum dalam sebagaimana yang tercantum dalam Pasal 23 ayat (1)

\footnotetext{
${ }^{16}$ Satjipto Rahardjo, Op.Cit., hlm. 167.
} 
PERPPU Nomor 1 Tahun 2020 Tentang Kebijakan Keuangan Negara Dan Stabilitas Sistem Keuangan Untuk Penanganan Pandemi Corona Virus Disease 2019 (COVID-19) Dan/Atau Dalam Rangka Menghadapi Ancaman Yang Membahayakan Perekonomian Nasional Dan/Atau Stabilitas Sistem Keuangan belum memperhatikan aspek perlindungan dan kepastian Hukum bagi Hak-Hak para Pemegang Saham yang telah dijamin dalam UUPT dan memperkuat sifat keotoriteran yang dapat mengakibatkan celah adanya perbuatan melawan hukum oleh OJK sehingga terjadinya Akuisisi dengan paksa atau dalam peristilahan lain disebut dengan Hostile Takeover. Lebih lanjut, dalam rangka mengoptimalisasikan perlindungan bagi pemegang saham, Kekosongan hukum dalam menetapkan Bank jenis apa yang dapat diberikan perintah tertulis perlu diperjelas karena dalam perintah tertulis dari OJK tersebut dapat juga merugikan pemegang saham diantaranya hilangnya posisi sebagai pemegang saham pengendali ataupun pihak pemegang saham utama, mengalami risiko dilusi atas kepemilikan saham, serta ancaman sanksi pidana bagi yang tidak menjalankan perintah tertulis OJK dalam pelaksanaan akuisisi Bank padahal UUPT mengatur independensi hak pemegang saham dalam RUPS.

Dalam memformulasikan konsep pemecahan masalah dalam mencapai nilai keadilan seharusnya legislator mempertimbangkan keselarasan antara perlindungan bagi investor, kepentingan otoritas, dan kepentingan publik dikarenakan Bank merupakan badan usaha yang melibatkan banyak pihak sehingga tidak tepat pemecahan masalah dengan model keotoriteran dari Pemerintah yang mendelegasikan kewenangan tersebut kepada OJK yang dapat mengatur sedemikian rupa terhadap segala tindakan Bank terlebih lagi mengintervensi RUPS. Kebijakan yang dikeluarkan oleh pemerintah seharusnya juga memperkuat atau mengoptimalisasikan Hak-Hak Pemegang Saham disamping penguatan kewenangan OJK dalam pelaksanaan Akuisisi di LJK Bank sehingga tidak melahirkan Hostile Takeover yang tentu akan berpengaruh pada Investor yang ingin menyertakan Modalnya. Standarisasi dari sebuah unsur kegentingan yang memaksa perlu ditetapkan atau dievaluasi oleh Pemerintah sehingga Bank jenis apa yang dapat ditetapkan sebagai Bank yang harus menjalankan perintah dari OJK untuk melakukan penggabungan, peleburan, pengambilalihan, integrasi dan/atau konversi sehingga diskresi yang dikeluarkan oleh OJK tidak bersifat tendensius, dan berpotensi menyalahgunakan wewenang.

\section{DAFTAR PUSTAKA}

\section{Buku}

Binoto Nadapdap, Hukum Perseroan Terbatas, Jakarta: Jala Permata Aksara, 2018.

Budiono Kusumohamidjojo, Teori Hukum: Dilema antara Hukum dan Kekuasaan, Bandung: Yrama Widya, 2017.

Munir Fuady, Hukum Tentang Akuisisi, Take Over dan LBO, Jakarta: PT Citra Aditya Bakti, 2001.

Robert Prayoko, Doktrin Business Judgement Rule: Aplikasinya Dalam Hukum Perusahaan Modern, Yogyakarta: Graha Ilmu, 2015.

Satjipto Rahardjo, Ilmu Hukum, Bandung: Citra Aditya, 2000. 
Dialogia luridica: Jurnal Hukum Bisnis dan Investasi

Volume 12, Nomor 2, April 2021

\section{Jurnal}

Agata Kocia, et al. "PFSA and BaFin - Comparison of Institutional Framework in Dynamic Financial Markets", Journal of Applied Business and Economics, Volume 13 No. 2, 2012.

Ahmad Solahudin, "Pemisahan Kewenangan Bank Indonesia Dengan Otoritas Jasa Keuangan Dalam Pengawasan Bank", Jurnal IUS: Kajian Hukum dan Keadilan, Volume 3, No. 7, 2015.

Indria Kinasih Khameswary, "Good Corporate Goverernance dan Kurang Efektifnya Direktur Independen di Indonesia”, Jurnal Gema Keadilan, Volume 6, Edisi II, Juni 2019

Jesse M. Fried, "Powering Preemptive Rights with Presubscription Disclosure", Harvard:

John M. Olin Center for Law, Economics, And Busines, Discussion Paper No. 973, 2018.

Niru Anita Sinaga, "Peranan Asas-Asas Hukum Perjanjian Dalam Mewujudkan Tujuan Perjanjian”, Jurnal Bina Mulia Hukum, Volume 7 No. 2, 2018.

Rebekka Dosma Sinaga, et al., "Sistem Koordinasi Antara Bank Indonesia Dan Otoritas Jasa Keuangan Dalam Pengawasan Bank Setelah Lahirnya Undang-Undang Nomor 21 Tahun 2011 Tentang Otoritas Jasa Keuangan", Transparency Journal of Economic Law, Volume 1 No. 2, 2002.

Steven Siaila, et al., "Studi Kelayakan Pengembangan Rumah Sakit Sumber Hidup Gereja Protestan Maluku Di Kota Ambon”, Jurnal SOSOQ, Volume 7 No. 2, 2019.

\section{Penelitian/ Tugas Akhir:}

Diana Fajarwati, Analisis Penerapan Prinsip - Prinsip Good Corporate Governance di Lingkungan Internal Perusahaan Umum Badan Urusan Logistik (Perum Bulog), Skripsi dari Fakultas Ilmu Sosial dan Politik Universitas Indonesia, 2011.

Samim Zarin, et al., Mergers \& Acquisitions: Hostile Takeovers and Defense Strategies Against Them, Bachelor thesis in International Business, Department of Business \& Administration, University of Gothenburg, 2011.

Srilaksmi Nuri Indradewi, Hostile Takeover Melalui Bursa Efek Terhadap Perseroan Terbatas Terbuka, Tesis pada Fakultas Hukum Universitas Airlangga, Surabaya, 2003.

\section{Peraturan Perundang-Undangan}

Republik Indonesia. Undang-Undang Dasar Negara Republik Indonesia Tahun 1945. UUD 1945. Naskah Asli - Undang-Undang Dasar Negara Republik Indonesia Tahun 1945, Undang-Undang Dasar Negara Republik Indonesia Tahun 1945. Kitab Undang-Undang Hukum Perdata. . Undang-Undang Nomor 7 Tahun 1992 Tentang Perbankan sebagaimana telah diubah dengan Undang-Undang Nomor 10 Tahun 1998. . Undang-Undang Nomor 8 Tahun 1995 Tentang Pasar Modal. Undang-Undang Nomor 40 Tahun 2007 Tentang Perseroan Terbatas. . Undang-Undang Nomor 21 Tahun 2011 Tentang Otoritas Jasa Keuangan. 
Krisis Sistem Keuangan.

Undang-Undang Nomor 9 Tahun 2016 Pencegahan Dan Penanganan . PERPPU Nomor 1 Tahun 2020 Tentang Kebijakan Keuangan Negara

Dan Stabilitas Sistem Keuangan Untuk Penanganan Pandemi Corona Virus Disease 2019

(COVID-19) Dan/Atau Dalam Rangka Menghadapi Ancaman Yang Membahayakan

Perekonomian Nasional Dan/Atau Stabilitas Sistem Keuangan. . POJK Nomor 32 /POJK.04/2014 Tahun 2014 Tentang Rencana

Penyelenggaraan RUPS Perusahaan Terbuka. . POJK Nomor 11 /POJK.03/2016 Tentang Kewajiban Penyediaan Modal

Minimum Bank Umum. . POJK No. 34/ POJK.03/ 2018 Tentang Penilaian Kembali Bagi Pihak Utama Lembaga Jasa Keuangan.

POJK Nomor 14/POJK.04/2019 Tahun 2019 Tentang Perubahan atas

POJK Nomor 32/POJK.04/2015 Tentang Penambahan Modal Perusahaan Terbuka Dengan Memberikan Hak Memesan Efek Terlebih Dahulu.

POJK 41/POJK.03/2019 tentang Penggabungan, Peleburan,

Pengambilalihan, Integrasi, dan Konversi Bank Umum.

. Surat Edaran Otoritas Jasa Keuangan Nomor 39 /SEOJK.03/2016

Tentang Penilaian Kemampuan Dan Kepatutan Bagi Calon Pemegang Saham

Pengendali, Calon Anggota Direksi Dan Calon Anggota Dewan Komisaris

Directive (EU) 2017/828 Of The European Parliament And Of The Council of 17 May 2017.

\section{Pranala Luar}

https://finansial.bisnis.com/read/20190731/90/1130993/laba-bank-bukopin-kembali-merosot

(diakses pada tanggal 6 september 2020).

https://keuangan.kontan.co.id/news/kurang-dari-setahun-sudah-tiga-direksi-bukopin-

mengundurkan-diri (diakses pada tanggal 6 september 2020).

https://www.cnbcindonesia.com/market/20200827160422-17-182507/bos-bosowa-ada-

indikasi-hostile-takeover-bukopin (diakses pada tanggal 7 September 2020). 